\title{
Chapter 44 \\ Global Crop Improvement Networks to Bridge Technology Gaps
}

\author{
Michael Baum, Wuletaw Tadesse, Miloudi Nachit, Osman Abdalla, \\ Sanjaya Rajaram, Ravi Singh, Tomas Payne, Karim Ammar, \\ Alex Morgounov, and Hans Braun
}

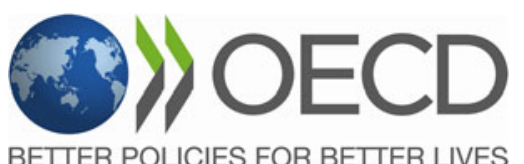

The opinions expressed and arguments employed in this publication are the sole responsibility of the authors and do not necessarily reflect those of the OECD or of the governments of its Member countries.

The Special Session was sponsored by the OECD Co-operative Research Programme on Biological Resource Management for Sustainable Agricultural Systems, whose financial support made it possible for most of the invited speakers to participate in the Special Session.

\begin{abstract}
The International Wheat Improvement Network (IWIN), an alliance of national agricultural research systems (NARSs), International Maize and Wheat Improvement Center (CIMMYT), International Center for Agricultural Research in the Dry Areas (ICARDA), and advanced research institutes (ARIs), continues to deploy cutting-edge science alongside practical multi-disciplinary applications, resulting in the development of germplasm that has made major contributions during the Green Revolution. The continuous supply of improved germplasm for nearly half a century has also enabled developing countries to have a sustained increase of wheat production and productivity and thereby improving food security and farmers'
\end{abstract}

M. Baum $(\bowtie)$

International Center for Agricultural Research in the Dry Areas (ICARDA), Amman, Jordan

e-mail:m.baum@cgiar.org

W. Tadesse $\bullet$ M. Nachit

International Center for Agricultural Research in the Dry Areas (ICARDA), Rabat, Morocco 
livelihoods. Wheat production levels have increased from 235 million tons in 1961 to 691 million tons in 2012. Yet, global food consumption has exceeded production for 6 of the last 11 years (2004-2010), and food reserves are now 'dangerously low, particularly for staple grains such as wheat and maize. Changing diets, urbanization, and other factors mean that demand for wheat is likely to only multiply further, and therefore wheat yields must increase from the current global average of $3 \mathrm{t}$ per hectare. According to some estimates, the global wheat production must increase at least by $1.6 \%$ annually to meet a projected yearly wheat demand of 760 million tons by 2020. In the year 2050, the world population is estimated to be nine billion and the demand for wheat reaches more than 900 million tons. Fulfilling this demand is very challenging with the current scenario of climate change, increasing drought/ water shortage, soil degradation, reduced supply $\&$ increasing cost of fertilizers, increasing demand for bio-fuel, and emergence of new virulent diseases and pests. This paper presents a review and insight about the past and current contributions of IWIN, breeding progresses and genetic gains, and its future role in offsetting the major global challenges of wheat production.

\section{Introduction}

Wheat is one of the leading cereal crops which have provided daily sustenance for a large proportion of the world's population for millennia. According to FAO (2012), about 651 million tons of wheat was produced on average of 217 million ha with productivity level of $3.1 \mathrm{t} \mathrm{ha}^{-1}$. The Central and West Asia and North Africa (CWANA) region produces more than 100 million tons of wheat in a total area of 55 million hectares at a productivity level of $2 \mathrm{t} / \mathrm{ha}$ which is less than the worlds average (3 t/ha) (Fig. 44.1).

Most of the wheat production in the developed world is rainfed while in the developing world, especially in the large producers India and China, more than half of the wheat area is irrigated. Wheat productivity varies not only between irrigated and rainfed production systems but also between countries applying similar agronomic practices. For example, among major rainfed wheat producers, the average national yield ranges from about $0.9 \mathrm{t} \mathrm{ha}^{-1}$ in Kazakhstan to $2.6 \mathrm{t} \mathrm{ha}^{-1}$ in Canada and up to $7.9 \mathrm{t} \mathrm{ha}^{-1}$ in the United Kingdom (FAO, 2005). Among major irrigated wheat

O. Abdalla

International Center for Agricultural Research in the Dry Areas (ICARDA), Cairo, Egypt

S. Rajaram

International Center for Agricultural Research in the Dry Areas (ICARDA), Mexico, Mexico

R. Singh $\bullet$ T. Payne $\bullet$ K. Ammar $\bullet$ H. Braun

International Maize and Wheat Improvement Center (CIMMYT), Mexico, Mexico

A. Morgounov

International Maize and Wheat Improvement Center (CIMMYT), Ankara, Turkey 


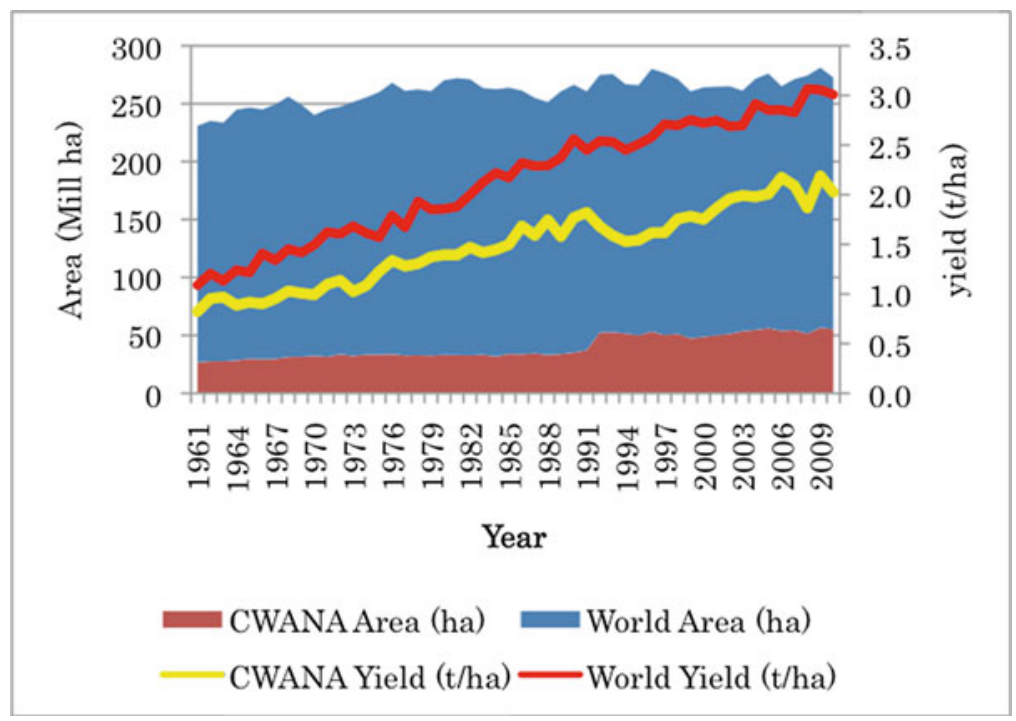

Fig. 44.1 Production area and yield of wheat in the world and CWANA, 1961-2010

producers, India has an average yield of $2.6 \mathrm{t} \mathrm{ha}^{-1}$ compared with $6.5 \mathrm{t} \mathrm{ha}^{-1}$ in Egypt. This clearly indicates the possibility of increasing wheat productivity in many countries by improving their respective wheat production packages.

The low productivity of wheat in the developing countries especially those in the CWANA region is due to abiotic stresses (drought, cold, heat, salinity) and biotic stresses (yellow rust, leaf rust, stem rust, root rots, Russian Wheat Aphid, Barley Yellow Dwarf Virus, Sunn pest, and Hessian Fly). Principally, drought and yellow rust are the most important wheat yield limiting factors. With the current climate change, it is anticipated that new pests and diseases will emerge as already exemplified in the recent epidemics of yellow rust across the CWANA region and Ug99 epidemic in East African countries. The effect of climate change is also evident on the quality of wheat as increased heat results in shriveled wheat grains.

The International Wheat Improvement Network (IWIN), which is an alliance of International Research Centers (CIMMYT \& ICARDA), national agricultural research systems (NARSs) and ARIs, has contributed significantly to the development of germplasm that has made major contributions to the green revolution and to improving food security and farmers' livelihoods in many developing countries (Dixon et al. 2009). In this specific instance, it is noteworthy to mention Dr. Norman Borlaug, who has developed the semi-dwarf input responsive wheat cultivars for the Green Revolution in Mexico, India, Pakistan, and Turkey and many other developing countries.

Starting from 2011, CIMMYT and ICARDA are implementing the WHEAT Consortium Research Program (CRP WHEAT) which is part of a concerted effort of the Consultative Group on International Agricultural Research (CGIAR) to implement a new, results-oriented strategy through a series of CRPs that fully exploit the potential of international agricultural research for development to 
enhance global food security and environmental sustainability. WHEAT draws on and potentiate the capacities and commitment of two leading international centers (CIMMYT and ICARDA), in partnership with farming communities, national research systems, advanced research institutes, private companies, policy makers, and diverse development organizations.

\section{Major Objectives of IWIN}

The general objective of IWIN is to enhance the productivity, yield stability, and end-use quality of wheat production at global level with major emphasis in the developing world.

Specific objectives:

- Develop high yielding and disease and pest resistant wheat genotypes with acceptable grain quality for irrigated and rain-fed production systems

- Identify germplasm for heat and salt tolerance

- Identify, map and pyramid major genes and QTLs for durable disease resistance and drought and heat tolerance

- Distribution of improved germplasm to NARS through the International wheat nursery and system

- Build capacity of NARS through long term and short term training in wheat breeding/genetics

\section{Breeding Methods and Approaches}

The wheat breeding program at CIMMYT and ICARDA applies both conventional and molecular breeding approaches and techniques in order to develop high yielding and widely adapted germplasm with resistance/tolerance to the major biotic and abiotic constraints prevailing in the developing world. Some of these strategies and techniques include classification of Mega-Environments (ME) and assembling of targeted crossing blocks, shuttle breeding, utilization of doubled haploids (DH) and marker assisted selection (MAS), key location yield trials, distribution of germplasm to NARS through international nurseries, and partnership \& capacity building of NARS (Rajaram et al. 1995; Ferrara et al. 1987; van Ginkel et al. 2002; Ortiz et al. 2007; Tadesse et al. 2012a). As water is becoming scarce even in the irrigated areas, IWIN's germplasm development approach is to identify genotypes with disease resistance, high yield potential and water use efficiency so that wheat genotypes targeted for irrigated areas can cope with temporary drought periods. Similarly, this approach enables to minimize and maximize yield gains during drought and good seasons, respectively, for the rain fed production system.

Principally, high yielding and adapted hall mark wheat cultivars representing each MEs, synthetic wheats and elite lines from CIMMYT/ICARDA breeding 
programs are used as parents. Physiological and molecular screening techniques in order to increase rates of genetic gains through (a) strategic trait-crossing to combine complementary traits in progeny, (b) high-throughput phenotyping to enrich for desirable alleles in intermediate generations and (c) exploration of genetic resources to broaden the genetic base for hybridization (Reynolds and Tuberosa 2008). Marker-assisted selection using recommended diagnostic markers is used in order to characterize new parental materials for disease resistance genes (yellow rust, leaf rust, stem rust, nematodes); insect resistance (Hessian fly and Russian Wheat Aphid), phenological traits such as photoperiodism $(P p d)$, vernalization requirement (Vrn); plant height (Rht), grain hardness and other genes (Gupta et al. 1999; Tadesse et al. 2012a). Diagnostic markers are also used for gene pyramiding in the $F_{2}, F_{1}$ top, and $B_{1} F_{1}$ populations (William et al. 2007). Segregating generations and fixed genotypes are evaluated in key locations using a shuttle breeding approach in order to develop disease resistant, high yielding, widely adapted and photoperiod insensitive genotypes within a short period of time.

\section{Germplasm Distribution and Capacity Development}

Based on request, different forms of germplasm such as genetic stocks for crossing bloc, segregating generations and finished (fixed) genotypes have been distributed globally on annual basis through the International Nursery system from CIMMYT and ICARDA. The genetic stocks and the segregating generations were sent with the objective of decentralizing the breeding program and creating genetic variability; while the fixed materials were sent with the objective of releasing adapted genotypes as varieties. The experience obtained so far is that most NARSs have released more varieties from directly introduced, semi-finished material than from early segregating populations (Byerlee and Moya 1993). Research infrastructure, budget availability, and overall strength of NARSs are the main factors accounting for these differences. As a matter of fact, unless specifically requested, most of the germplasm distribution to NARS from the CIMMYT/ICARDA wheat breeding program is semi-finished and finished materials.

All nurseries are distributed on annual basis based on the request from the national research programs across different regions of the world (Fig. 44.2). More than 620 co-operators requested the WHEAT nurseries during the 2013 season.

Germplasm distribution to the NARS by its own will not bring the expected result of releasing and adoption of improved varieties unless it is handled and managed by trained and qualified breeders. The wheat breeding programs at CIMMYT and ICARDA used to have both short and long term trainings in wheat breeding, and have trained hundreds of wheat breeders from all over the wheat growing NARSs. This had helped in the promotion of the ideals of international wheat breeding, and development and release of many wheat varieties. However, research and infrastructural support for public institutions that train plant breeders, and scientists in related disciplines, has steadily declined over the past three decades in most of 


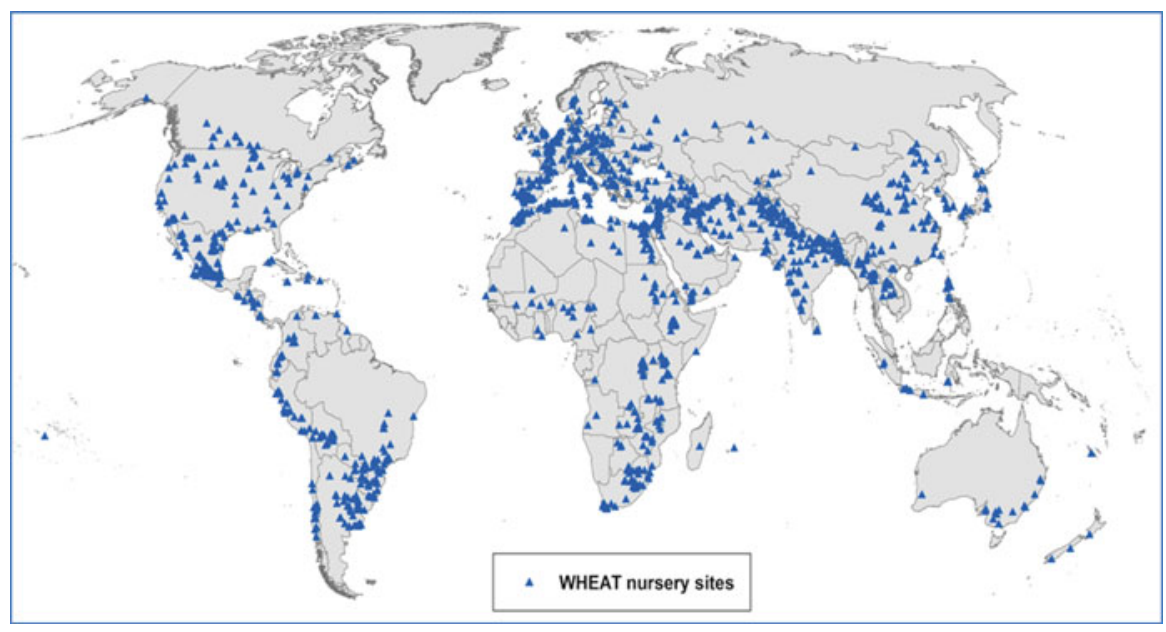

Fig. 44.2 Test sites of CIMMYT and ICARDA wheat international nurseries in 2012/2013

the developing countries NARS resulting in a great lack of trained agricultural researchers (FAO 2005). In the last decade many new technologies such as molecular markers have been rapidly developed and utilized in crop breeding institutes of the developed world. Such rapid advances in biotechnology and molecular genetics not only provide unprecedented opportunities to enhance breeding efficiency, but also create new challenges in training breeders with skills integrating both conventional and molecular breeding approaches and techniques. To this end, the wheat breeding programs at CIMMYT and ICARDA have established a training program on classical and molecular approaches for wheat improvement through which junior and mid-career scientists experience a comprehensive hands-on course on breeding for durable resistance, high yield potential and stability, drought tolerance, seed quality, and seed health issues using conventional and molecular tools.

\section{Variety Release, Adoption and Impacts}

The success of wheat improvement within the CGIAR has been remarkable, and today more than $70 \%$ of all spring wheat cultivars grown in developing countries are CIMMYT- and ICARDA-derived, reaching $90 \%$ in South Asia, parts of West Asia and North Africa (Byerlee and Moya 1993; Lantican et al. 2005) (Fig. 44.3). The impact of WHEAT has been witnessed not only by farmers, governments, policy makers and professionals but also by donors such as the World Bank. According to World Bank (2008), for no other major crop is the percentage of improved cultivars in farmers' fields in developing countries higher than for wheat. From the CIMMYT/ICARDA wheat breeding program, it has been reported that more than 1,500 wheat varieties have been released during the periods of 1966-1990 with 


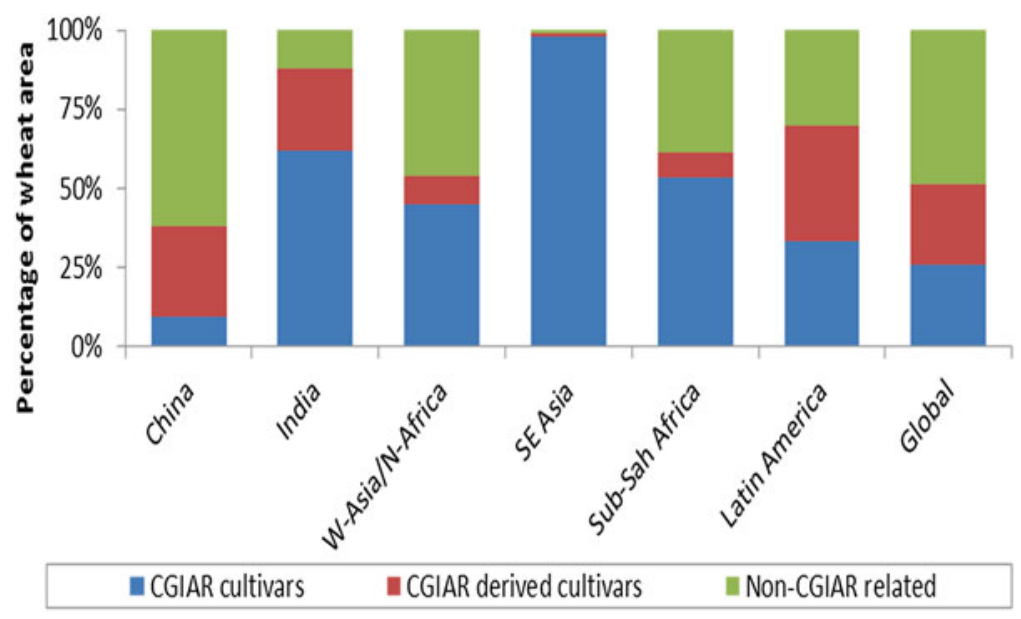

Fig. 44.3 Global and regional area coverage of CGIAR and non-CGIAR origin wheat cultivars

average of 65 varieties released annually. More than $80 \%$ of the varieties released are spring bread wheat, which account for $77 \%$ of the wheat area in the developing world outside of China (Byerlee and Moya 1993). Among the many crosses developed to-date at CIMMYT/ICARDA, the VEERY cross (KVZ/BUHO//KAL/BB) and its derivatives have been by far the most successful cross enabling in the release of at least 65 varieties in more than 30 countries. Among the VEERYs, Veery 5 (CM33027-F-15 M-500Y-0 M) was the most popular and released in many countries with different local names such as SERI 82 in Lebanon, Turkey, Mexico; Dashen in Ethiopia; Tilila in Morocco; Aziz in Yemen; Pirsabak 85 in Pakistan; Loerie in Zambia; MACS2496 in India; SCW101 in Zimbabwe; Rassol in Iran; GIZA 164 in Egypt; SASARAIB in Sudan and TAUSI in Tanzania.

After the VEERYs, Cham-6 (W3918A/JUP) also called Neser was released and grown in Syria, Lebanon, Jordan, Iraq and Algeria. Similarly, Kauz (JUP/BJY// URES) has been released in many countries with different local names such as Cham-8 in Syria, Tanur in Lebanon, Mehdia in Morocco, Atrak in Iran, Bacanora in Mexico, WH 542 in India and with other different names in many other countries. After Kauz, many successful varieties have been originated from the Attila cross (ND/VG9144//KAL/BB/3/YACO/4/VEE\#5) and grown in many countries as megacultivars such as Kubsa in Ethiopia; Imam in Sudan; Utique 96 in Tunisia; PBW343 in India; Chamran, Gaher and Shiroodi in Iran; Ziyabey 98 in Jordan; MH-97 in Pakistan; and with different names many other countries (Tadesse et al. 2010). Recently, from the CIMMYT/ICARDA wheat breeding programs, Ug99 resistant wheat varieties have been released in many countries.

Adoption studies of the modern varieties (MVs) originated from the CIMMYT/ ICARDA program have indicated that in the 1990s, MVs covered close to 50 million hectares, or $70 \%$ of the wheat area in the developing world, excluding China (Byerlee and Moya 1993). According to their report, spring bread wheat varieties 
have been the most successful with MVs occupying an estimated $85 \%$ of spring bread wheat area and account for $93 \%$ of production. Since spring bread wheat dominates developing country wheat production (about $70 \%$ of the total), success in spring bread wheat accounts for the overall large area sown to semi-dwarfs. Though estimating the economic impact of the CIMMYT/ICARDA international wheat breeding program is very difficult given the diversity of environments and number of countries and research programs involved, Byerlee and Moya (1993), reported that the adoption of MVs of spring bread wheat over 1977-1990 resulted in about 15.5 million tons of additional wheat production in 1990, valued at about US\$ three billion. For the spring wheat areas under consideration, this amounts to a production increase of $16 \%$ (an increase of about $1.1 \%$ annually over the period). Nearly $80 \%$ of all durum wheat cultivars in developing countries are CIMMYT-ICARDA selections.

An adoption study conducted in Syria by the Farm Resource Management Program (FRMP) of ICARDA during 1991 showed that, modern high-yielding varieties (HYVs) such as Bohouth 2, 4, and 6; and Cham 2, 4, 6, 8, and 10 account for $87 \%$ of the area planted and were grown by $86 \%$ of the farmers surveyed (Tutwiler and Mazid 1991). The area planted by Mexipak 65 has dramatically reduced in the year 2000 and since 2005 Cham 8 covers more than $50 \%$ of the spring bread wheat production area in Syria. Semi-dwarf durum wheat became available in the early 1970s, and now over half of the durum wheat area is sown to MVs. MVs of durum wheat such as Bohouth 1, Cham 1, Cham 3 and Cham 5, which were originated from the CIMMYT/ICARDA wheat breeding program, have been released and widely grown in Syria (Nachit 1992; Nachit et al. 1995). The utilization and adoption of such MVs of bread and durum wheat coupled by supplementary irrigation and other inputs such as fertilizers and herbicides by the Syrian farmers has increased the wheat production significantly without a change in the area of wheat production as indicated in Fig. 44.4.

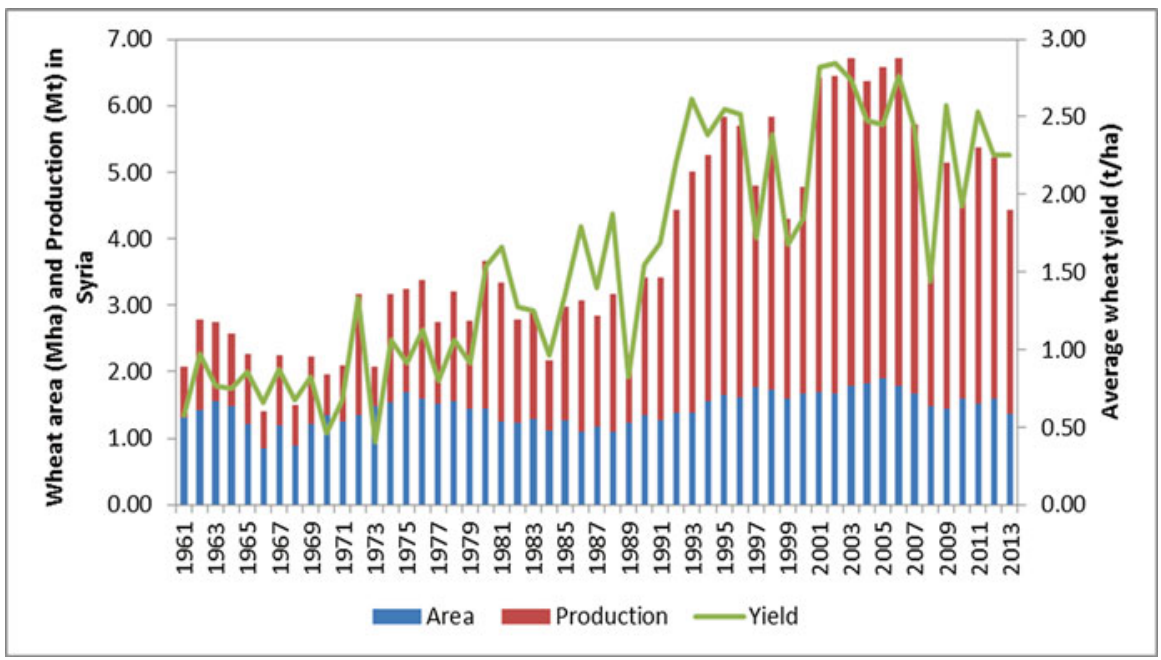

Fig. 44.4 Area, production and yield of wheat in Syria, 1961-2013 
International breeding efforts focusing only on winter wheat started since 1986 through the establishment of International Winter Wheat Improvement Program (IWWIP). To-date more than 55 winter/facultative wheat varieties of IWWIP origin have been released in 10 countries of Central and West Asia including Afghanistan, Iran and Turkey (Tadesse et al. 2013). These new varieties have broad genetic diversity as they are developed from parents of diverse sources originated from ICARDA, CIMMYT, and from a wide range of genetically unrelated winter wheat from Turkey, Iran, Russia, Ukraine, Romania, Bulgaria, Hungary and US. Some lines such as OK82282//BOW/NKT and YMH/TOB//MCD/3/LIRA have been identified and released under different names in different countries indicating their broad adaptation. The former is released in Afghanistan and Kyrgyzstan while the later (Kinaci 97) has been released in Turkey, Afghanistan and Uzbekistan. However, MVs of winter wheat still cover a small area. Old cultivars such as Bezostaya and Gereek are dominantly cultivated in Turkey.

\section{Breeding Progress}

Development and identification of high yielding genotypes with wide adaptation and resistance to biotic and abiotic stresses remain the top priorities of the wheat breeding programs. There are different approaches of determining the breeding progress or the rate of genetic gain for grain yield and other traits. Some studies use yield of historical genotypes grown in the same environment while others have used mean yield to examine progress over time in highly productive environments. Trethowan et al. (2002) have used regression analysis using the mean of the five highest yielding entries expressed as per cent of the trial mean across years to determine the rate of breeding progress in elite spring wheat yield trial (ESWYT) and semi-arid wheat yield trial (SAWYT). Tadesse et al. (2010) have used success rate analysis of best lines for the high rain-fall wheat yield trials (HRWYT) of CIMMYT to demonstrate yield gains over years or trials. Genetic gain studies for the CIMMYT/ ICARDA wheat breeding program have shown continuous progress in yield and other traits (Sayre et al. 1997; Trethowan et al. 2002; Sharma et al. 2012; Tadesse et al. 2010). Recently, Tadesse et al. (2013) have determined the breeding progress for IWWIP and reported that the grain yield of the best line (BL) increased at a rate of $110 \mathrm{~kg} / \mathrm{ha} /$ year $\left(\mathrm{R}^{2}=0.66 ; \mathrm{P}=0.001\right)$, while the trial mean $(\mathrm{TM})$ increased at a rate of $91.9 \mathrm{~kg} / \mathrm{ha} /$ year $\left(\mathrm{R}^{2}=0.53 ; \mathrm{P}=0.007\right)$ indicating a continuous yield improvement at IWWIP.

In addition to grain yield, significant progress has been made by the IWIN in developing resistant wheat germplasm to diseases and pests ensuring that developing and deploying genetically resistant varieties adapted to target growing environments is the best economical and environmentally friendly strategy for controlling rust diseases of wheat particularly for resource poor farmers. However, because of the co-evolution of the host and pathogen, the deployment of individual 
resistance genes leads to the emergence of new virulent pathogen mutants, and hence the 'boom and bust cycle' of cultivars performance continues. Recently, a new stem rust race Ug99 (TTKS) has been first detected in Uganda in 1999 and then spread to Kenya, Ethiopia, Yemen, Sudan and Iran, and became a global threat to the wheat industry of the world for the very fact that it over comes many of the known and most common stem rust resistance genes such as $\operatorname{Sr} 31, \operatorname{Sr} 24$ and $\mathrm{Sr} 36$ (Singh et al. 2006; Jin et al. 2007; Haile et al. 2012). Similarly, the breakdown of yellow rust resistance genes $\operatorname{Yr} 9$ in cultivars derived from "Veery" in the 1980s and Yr27 in 2000s in major mega cultivars derived from "Attila" cross such as PBW343 (India), Inquilab-91 (Pakistan), Kubsa (Ethiopia) and others such as Achtar in Morocco, Hidab in Algeria and many other cultivars in the CWANA region (Solh et al. 2012) has caused significant wheat production loss. Through a coordinated international effort, many wheat varieties resistant to Ug99 and yellow rust have been released and replaced the susceptible cultivars.

In most developing countries, apart from grain yield and disease resistance, grain quality was not a strong criterion of variety selection. However, things have changed through time and some developing NARS are critically looking for better quality varieties suiting for preparation of different end products. Varieties such as Bezostaya, Achtar, Veery, HD1220, and Pavon-76 are known for their excellent grain quality. These varieties are still dominantly grown in some countries not only because of their wide adaptation, high yield potential and stability but also because of their high protein content and quality. With this understanding the wheat breeding programs at CIMMYT and ICARDA undertake evaluation of germplasm for quality traits following standard grain quality procedures. Most of the currently available elite genotypes for both irrigated and rain fed environments are excellent in quality with protein levels of $12-16 \%$. Most of these genotypes have the $5+10$ $(G l u-D l), 7+8(G l u-B l)$ and $2 *(G l u-A l)$ alleles. These alleles, especially the $5+10$ $G l u-D 1$ allele, have been reported to be highly correlated with protein quality and are being used intensively as a selection criterion in wheat breeding for improving end-use quality.

\section{Future Directions and Prospects}

According to some estimates (Fischer 2009), the global wheat production must increase at least by $1.6 \%$ annually during 2005-2020 to meet a projected wheat demand of 760 million tons by 2020 . In the year 2050, the world population is estimated to be nine billion (Alexandratos 2009) and the demand for wheat reaches more than 900 million tons. Fulfilling this increasing demand for wheat is very challenging with the current scenario of climate change (IPCC 2007; Battisti and Naylor 2009), increasing drought/water shortage, soil degradation, reduced supply \& increasing cost of fertilizers, increasing demand for bio-fuel, and emergence of new 
virulent diseases and pests. Offsetting these challenges requires understanding of the drivers of past trends and future changes in wheat production, and designing an effective research strategy for gene mining, introgression and deployment with the application of new technologies and tools.

Located in the heart of the Fertile Crescent, ICARDA houses more than 41,000 wheat accessions of wheat including rich collections of landraces, primitive wheat, Aegilops and wild Triticum species. Synthetic hexaploid wheat (SHWs) produced by artificial resynthesis of bread wheat through hybridization between Ae. tauschii and $T$. turgidum are also available in the genebank. These wheat germplasm are novel sources of resistance genes against biotic and abiotic stresses for wheat production (Ogbonnaya et al. 2001; van Ginkel and Ogbonnaya 2007). However, despite the existence of this promising resource of new genes, there has been limited deployment and/or effective use in cultivated bread wheat mainly due to the high cost of screening of such huge number of accessions and the potential simultaneous transfer of deleterious genes. The development of Focused Identification of Germplasm Strategy (FIGS) and the availability of new molecular tools such as genotyping-by-sequencing (GBS) would enable to characterize and mine novel genes and alleles effectively and rapidly from such gene bank accessions. It is also important to apply modern tools including genome-wide selection, and advanced statistical analysis of multi-location evaluation data for wheat breeding in order to allow faster integration of desirable traits and improve breeding efficiency, especially for complex traits such as grain yield under optimum, drought, and heat conditions (Ferrara et al. 1987; Braun et al. 2010).

Major efforts are needed to break yield barrier in wheat to increase wheat yield potential by $50 \%$ in order to cope the growing demand for wheat. Increasing the radiation use efficiency of wheat through modification of key enzymes (e.g., Rubisco) and biochemical pathways to increase photosynthesis, ear size and lodging resistance are key areas of wheat research through integration of physiological and molecular breeding methodologies to increase wheat yield potential. Further increase in yield potential would be achieved through the development of hybrid wheat systems based on native and transgenic interventions in collaborative approach, leveraging private sector technologies for the benefit of partners and stakeholders in the developing world.

The International Wheat Improvement Network (IWIN) coordinated by CIMMYT and ICARDA has been the most successful and efficient network for making available and widespread distribution of new wheat genotypes globally (Payne 2004; Reynolds and Borlaug 2006; Dixon et al 2009; Byerlee and Dubin 2010). Such a network need to be strengthened through the establishment of other net-works and collaborations in order to develop, disseminate, and market more productive, stress tolerant, and nutritive wheat varieties, and to perfect and promote production practices based on the principles of conservation agriculture that boost yields while conserving or enhancing critical resources like soil and water. 
Open Access This chapter is distributed under the terms of the Creative Commons Attribution Noncommercial License, which permits any noncommercial use, distribution, and reproduction in any medium, provided the original author(s) and source are credited.

\section{References}

Alexandratos N (2009) Expert meeting on "How to feed the world in 2050". FAO, 24-26 June, 2009. Critical evaluation of selected projections

Battisti DS, Naylor RL (2009) Historical warnings of future food insecurity with unprecedented seasonal heat. Science 323:240-244

Braun HJ, Atlin G, Payne T (2010) Multi-location testing as a tool to identify plant response to global climate change. In: Reynolds CRP (ed) Climate change and crop production. CABI, London

Byerlee D, Dubin HJ (2010) Crop Improvement in the CGIAR as a global success story of open access and international sharing. Int J Common 4:452-480

Byerlee D, Moya P (1993) Impacts of international wheat breeding research in the developing world, 1966-1990. CIMMYT, Mexico, p 135

Dixon J, Braun HJ, Crouch J (2009) Transitioning wheat research to serve the future needs of the developing world. In: Dixon J, Braun HJ, Kosina P (eds) Wheat facts and futures 2009. CIMMYT, Mexico, pp 1-19

FAO (2005) Plant breeding and related biotechnology capacity assessments. (http://gipb.fao.org/ Web-FAO-PBBC/index.cfm?where=01)

FAO (2012) FAOSTAT agriculture data. Agricultural production 2009. FAO, Rome. Available at http://faostat.fao.org. Accessed 22 Apr 2012

Ferrara O, Mulitze D, Yau SK (1987) Bread wheat breeding for tolerance to thermal stresses occurring in West Asia and North Africa. In: Acevedo E, Fereres E, Gimenez C, Srivastava JP (eds) Improvement and management of winter cereals under temperature, drought stresses. INIA, Madrid, pp 267-282

Fischer G (2009) World food and agriculture to 2030/50: how do climate change and bioenergy alter the long-term outlook for food, agriculture and resource availability? Paper prepared for the expert meeting "How to feed the world in 2050". IIASA - paper for the EM. FAO, 24-26 June 2009

Gupta PK, Varshney RK, Sharma PC, Ramesh B (1999) Molecular markers and their application in wheat breeding. Plant Breed 118:369-390

Haile KJ, Hammer K, Badebo A et al (2012) Haplotype analysis of molecular markers linked to stem rust resistance genes in Ethiopian improved durum wheat varieties and tetraploid landraces. Genet Resour Crop Evol. doi:10.1007/s10722-012-9880-0

IPCC (2007) In: Salomon S, Quin D, Manning M et al (eds) Climate change 2007: the physical science basis. Contribution of working group I to the fourth assessment report of the intergovernmental panel on climate change. Cambridge University Press, Cambridge, UK/New York, p 996

Jin Y, Singh RP, Ward RW, Wanyera R, Kinyua M et al (2007) Characterization of seedling infection types and adult plant infection responses of monogenic Sr gene lines to race TTKS of Puccinia graminis f. sp. tritici. Plant Dis 91:1096-1099

Lantican MA, Dubin HJ, Morris ML (2005) Impacts of international wheat breeding research in the developing world, 1988-2002. CIMMYT, Mexico

Nachit MM (1992) Durum breeding for Mediterranean drylands of North Africa and West Asia. In: Rajaram S, Saari EE, Hettel GP (eds) Durum wheats: challenges and opportunities. CIMMYT, Mexico 
Nachit MM, Baum M, Impiglia A, Ketata H (1995) Studies on some grain quality traits in durum wheat grown in Mediterranean environments. In: Proceedings of the seminar on durum wheat quality in the Mediterranean regions, Zargoza, Nov 1995. Options Mediterraneennes Serie A, ICARDA/CIHEAM/CIMMYT 22:181-188

Ogbonnaya F, Seah I, Delibes A et al (2001) Molecular genetic characterisation of nematode resistance from Aegilops ventricosa and its derivatives in wheat. Theor Appl Genet 102:263-269

Ortiz R, Trethowan RM, Ferrara O et al (2007) High yield potential, shuttle breeding, genetic diversity, and a new international wheat improvement strategy. Euphytica 157:365-384

Payne T (2004) The international wheat improvement network (IWIN) at CIMMYT

Rajaram S, van Ginkel M, Fischer RA (1995) CIMMYT's wheat breeding mega-environments (ME). In: Proceedings of the 8th international wheat genetics symposium, Beijing

Reynolds M, Borlaug NE (2006) Impacts of breeding on international collaborative wheat improvement. J Agric Sci 144:3-17

Reynolds M, Tuberosa R (2008) Translational research impacting on crop productivity in droughtprone environments. Curr Opi Plant Biol 11:171-179

Sayre KD, Rajaram S, Fischer RA (1997) Yield potential progress in short bread wheats in northwest Mexico. Crop Sci 37:36-42

Sharma RC, Crossa J, Velu G, Huerta-Espino J, Vargas M, Payne TS, Singh RP (2012) Genetic gains for grain yield in CIMMYT spring bread wheat across international environments. Crop Sci 52:1522-1533

Singh RP, Hodson DP, Jin Y, Huerta-Espino J, Kinyua MG, Wanyera R, Njau P, Ward RW (2006) Current status, likely migration and strategies to mitigate the threat to wheat production from race Ug99 (TTKS) of stem rust pathogen. CAB Reviews: perspectives in Agriculture, Veterinary Science. Nutr Nat Resour 1(54):1-13

Solh M, Nazari K, Tadesse W, Wellings CR (2012) The growing threat of stripe rust world wide, Borlaug Global Rust Initiative (BGRI) conference, Beijing

Tadesse W, Manes Y, Singh R et al (2010) Adaptation and performance of CIMMYT spring wheat genotypes targeted to high rain fall areas of the world. Crop Sci 50:240-248

Tadesse W, Abdalla O, Ogbonnaya F et al (2012a) Agronomic performance of elite stem rust resistant spring wheat genotypes and association among trial sites in the CWANA region. Crop Sci. doi:10.2135/cropsci2011.09.0463

Tadesse W, Inagaki M, Tawkaz S et al (2012b) Recent advances and application of doubled haploids in wheat breeding. Afr J Biotechnol 89:15484-15492

Tadesse W, Morgounov AI, Braun HJ et al (2013) Breeding progress for yield and adaptation of winter wheat targeted to irrigated environments at the International Winter Wheat Improvement Program (IWWIP). Euphytica. doi:10.1007/s10681-013-0903-5

Trethowan RM, van Ginkel M, Rajaram S (2002) Progress in breeding wheat for yield and adaptation in global drought affected environments. Crop Sci 42:1441-1446

Tutwiler R, Mazid A (1991) Impact of modern wheat technology in Syria. Part one: the adoption of new technologies. Farm resource management program. Annual report 1991, pp 176-209

van Ginkel M, Ogbonnaya F (2007) Novel genetic diversity from synthetic wheats in breeding cultivars for changing production conditions. Field Crop Res 104:86-94

van Ginkel M, Trethowan RM, Ammar K, Wang J, Lillemo M (2002) Guide to bread wheat breeding at CIMMYT. Wheat special report no 5, Revised edn. CIMMYT, Mexico

William M, Trethowan R, Crosby-Galvan EM (2007) Wheat breeding assisted by markers: CIMMYT's experience. Euphytica 157:307-319

World Bank (2008) World development report, 2008. World Bank, Washington, DC 